\title{
HYPERVITAMINOSIS D WITH OSTEOSCLEROSIS
}

BY

\author{
LOREN T. DEWIND \\ From the Department of Medicine, University of Southern California, and the \\ Orthopaedic Hospital Medical Center, Los Angeles
}

(RECEIVED FOR PUBLICATION DECEMBER 12, 1960)

\begin{abstract}
Administration of vitamin $\mathrm{D}$ in high dosage produces extraosseous calcification, renal failure and usually hypercalcaemia, with a characteristic set of symptoms (Jeans, 1950). Its effects on bone have been alluded to in a number of publications (Jeans, 1950; Ross, 1952; Debré, 1948; Anning, Dawson, Dolby and Ingram, 1948; Ross and Williams, 1939; Tumulty and Howard, 1942; Danowski, Winkler and Peters, 1945; Howard and Meyer, 1948; Freeman, Rhoads and Yeager, 1946; Thatcher, 1931). In adults the characteristic roentgenologic bone finding is rarefaction. In children rarefaction is also reported, but with the additional finding of increased density of the zone of provisional calcification, and periosteal thickening (Ross, 1952).

The following case report demonstrates that excess ingestion of vitamin D may be accompanied by a severe degree of osteosclerosis, which is reversible, in addition to its better known effects.
\end{abstract}

\section{Case History}

A $5 \frac{1}{2}$-year-old white boy was admitted to the Orthopaedic Hospital Clinic complaining of pain in the right leg and flat feet. At the age of 3 he was considered elsewhere to have rickets on the basis of a 'peculiar feeling to the bones of the skull' and radiographs of the wrists. He was given two capsules of vitamin D daily, each containing 50,000 units, in addition to two tablespoons or more of cod liver oil and multivitamin drops. A few months after this he developed nausea and nontender recurrent lumps the size of half a lemon, over both tibias. His physician prescribed vitamin $\mathrm{C}$ and the lumps disappeared. In addition to the vitamin therapy at home, he was given a teaspoonful of cod liver oil daily at nursery school. After nine months of this therapy he became irritable, restless and nauseated, and the vitamins were stopped by the family. At the age of $4 \frac{1}{2}$, a diagnosis of rheumatic fever and anaemia was made and treatment was started with ferrous sulphate and sodium salicylate. His appetite was good, but he continued to be irritable and restless, sleeping only five hours at night. During the ensuing year his refusal to participate in school activities was ascribed by his teacher to stiffness in the extremities.

His birth weight was $8 \mathrm{lb} .8 \mathrm{oz}$. He was the son of a young woman who was married and separated before the child was born. Labour and delivery were normal. He was breast fed for eight months. He sat at 5 months, stood at 10 months, and walked at 11 months. His first tooth erupted at 4 months.

He was brought up chiefly by the mother's parents, while the mother worked. At an early age he had a tonsillectomy, adenoidectomy and circumcision. $\mathrm{He}$ also had measles.

Physical examination revealed an alert, hyperactive, well-developed and nourished white boy (Fig. 1). There was increased A-P diameter of the head with a suggestion of frontal and parietal bossing. The eyes, ears, nose and throat were normal. Dentition was normal, and the teeth appeared healthy. The thyroid gland was not

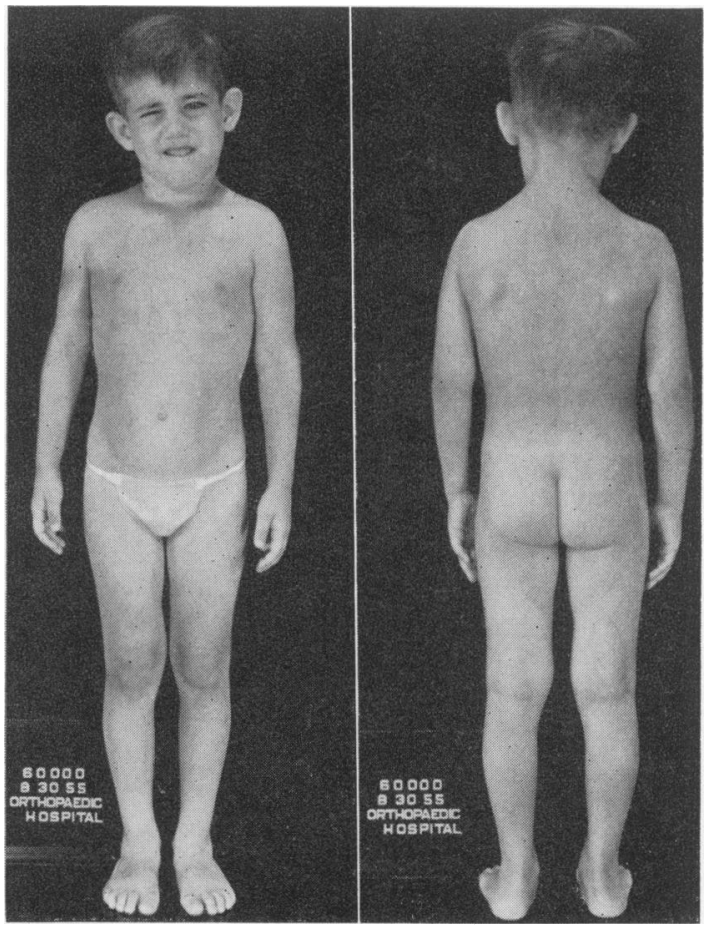

FIG. 1.-The patient at $5 \frac{1}{2}$ years of age. 


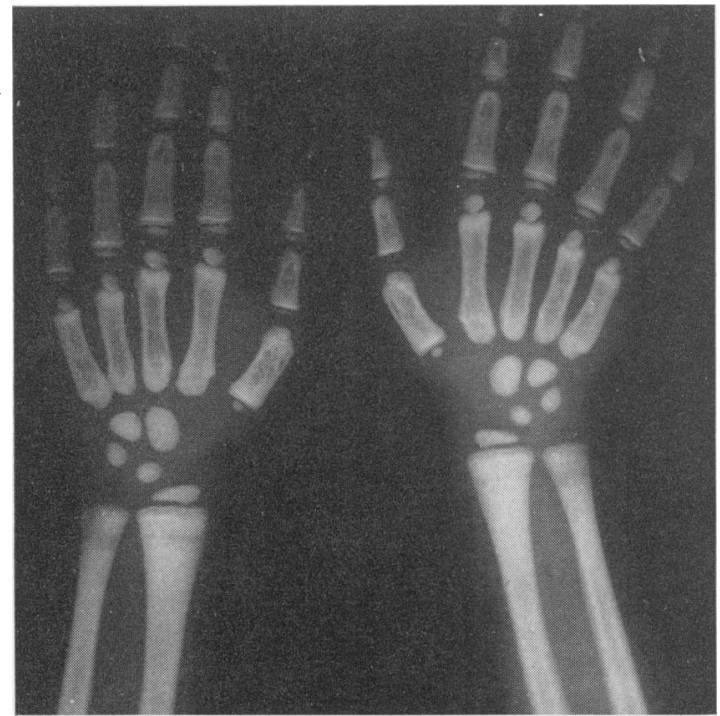

Fig. 2.-Radiograph at initial examination. Note alternating bands of decreased and increased density at ends of radius and ulna.

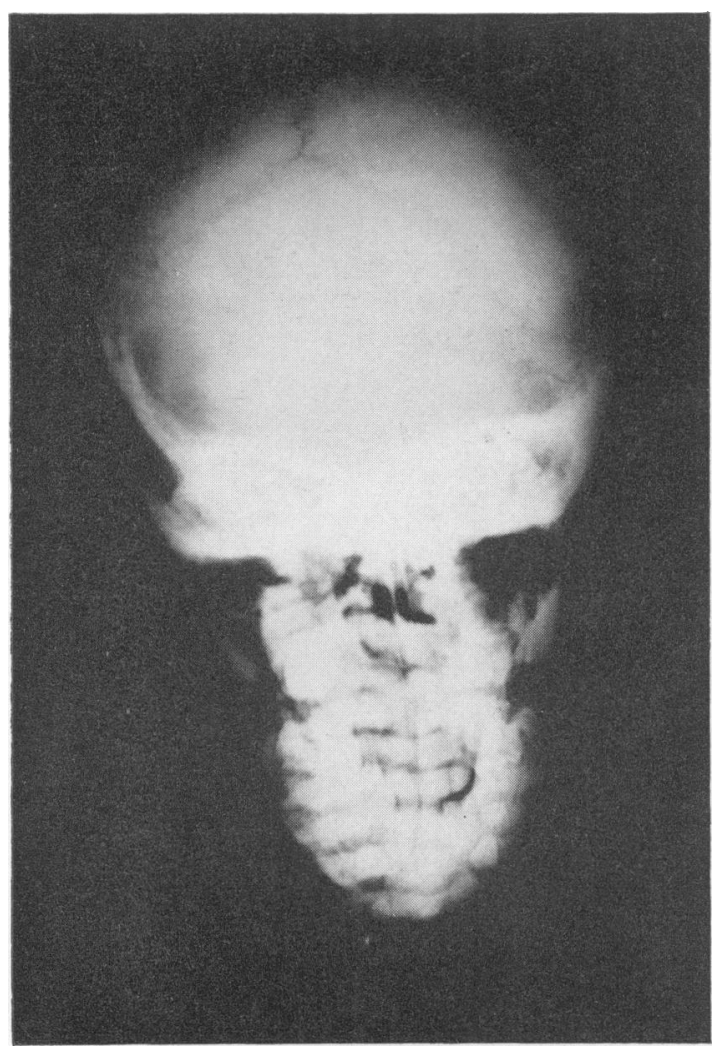

FIG. 3.-Skull showing generalized increase in density. palpable. The thorax showed beading of costochondral junctions. The heart, lungs and abdomen showed no abnormalities. The genitalia were normal for a boy of 5 . The testes were in the scrotum.

The epiphyseal regions of the long bones were stocky and broad. There was no tenderness or pain. There was eversion of the os calcis and loss of the longitudinal arch bilaterally. There was some spasm of the left rectus femoris muscle and 20 -degree flexion contractures of the knees. The skin was clear. There were no palpable calcific deposits anywhere. There was a healed ecchymosis on the lateral aspect of the right thigh.

A complete blood count showed $3 \cdot 70$ million erythrocytes, $12 \cdot 8 \mathrm{~g}$. haemoglobin, 10,400 leucocytes, with $40 \%$ polymorphs, $52 \%$ lymphocytes, $4 \%$ eosinophils, and $4 \%$ transitional forms. Urine analysis showed pale yellow urine of specific gravity 1,005 , acid reaction, no sugar, acetone, albumin or formed elements. Urine calcium was $0 \cdot 19 \mathrm{~g}$. in a 24 -hour volume of $1,750 \mathrm{ml}$. Serum calcium was $17 \mathrm{mg}$. per $100 \mathrm{ml}$., phosphorus $5.2 \mathrm{mg}$. per $100 \mathrm{ml}$, alkaline phosphatase $19 \mathrm{King}-$ Armstrong units, acid phosphatase $5 \cdot 3 \mathrm{King}$-Armstrong units, and protein-bound iodine $6.8 \mu \mathrm{g}$. \%. Radiographs showed generalized increase in density of the bones. Alternating bands of decreased and increased density were present in the metaphyses, best seen at the wrist (Fig. 2). The cortices of the metatarsals, metacarpals, and phalanges were thickened. Metaphyseal areas were a little wider than usual and remodelling had not proceeded normally. There was some encroachment on the medullary canals at the ends of the long bones and in the shaft, caused possibly by thickened cortex. The base of the skull and cranial vault were increased in density (Fig. 3). The petroclinoid ligaments were heavily calcified. Periarticular calcifications were present about the feet, hips, hands, ankles and shoulders. Kidney shadows were dense but not markedly so. The lumbar spine showed dense and square appearing vertebral bodies (Fig. 4). Intervertebral discs were not calcified. Soft tissue calcification or periosteal new bone could be made out along the sternum.

A chest film made two years previously showed no abnormalities in the lung fields, and normal bone density. Films of the wrists and skull made one and a half years previously showed normal bone density (Figs. 5-6). Zones of provisional calcification were maintained. The epiphyseal lines were not widened. Bony maturation corresponded satisfactorily with the given chronological age of 4 years. The skull showed no abnormalities. There was no roentgen evidence of rickets.

The family was instructed to stop administering vitamin $\mathrm{D}$ and presumably did so. They did not return for follow-up observation and care except sporadically, as he was under private care for general paediatric supervision.

Radiographs were obtained at seven, eight and 10 months after initial examination. An antero-posterior view of the pelvis after seven months showed a thin zone of decreased density about the pelvic bones, probably representing new growth (Fig. 7). Femoral 


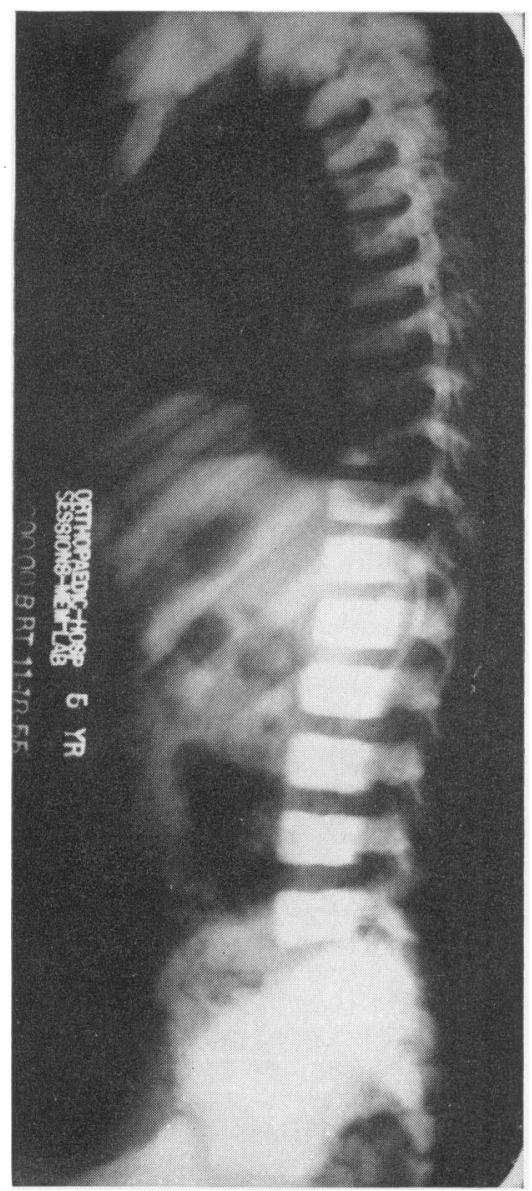

Fig. 4.-Note the dense square-appearing vertebral bodies.

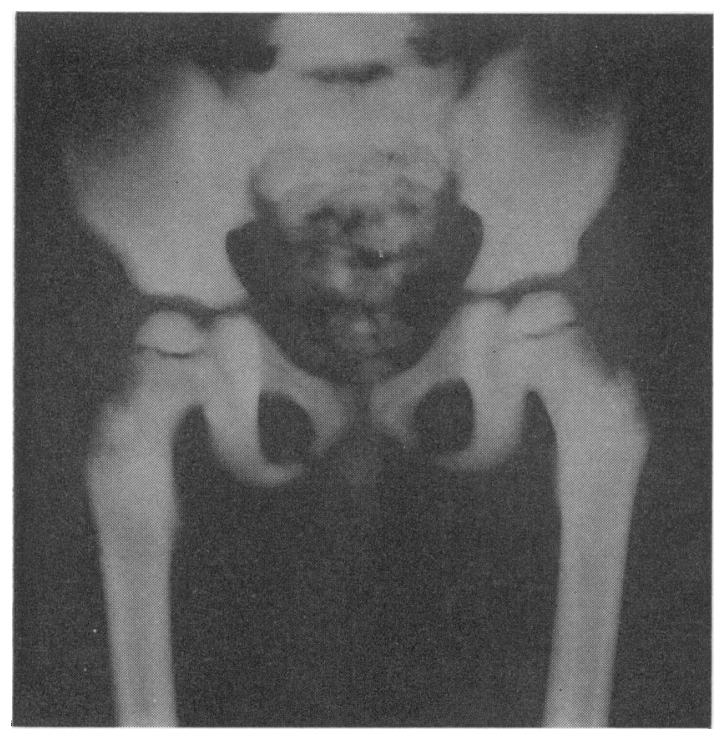

FIG. 7.-Pelvis seven months after discontinuing vitamin D.

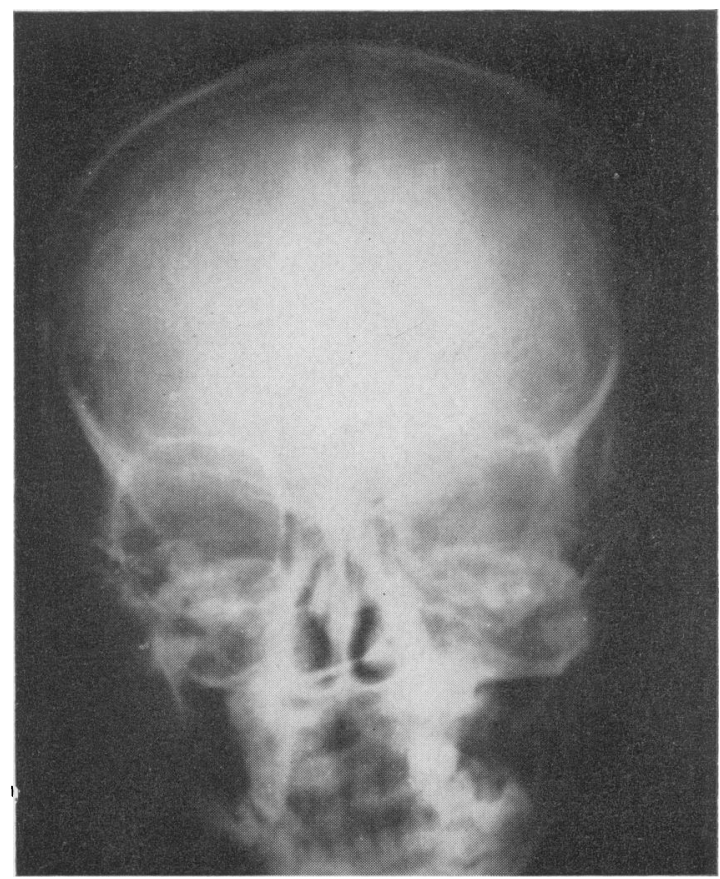

Fig. 6.-Normal appearing skull at the age of 4 . 


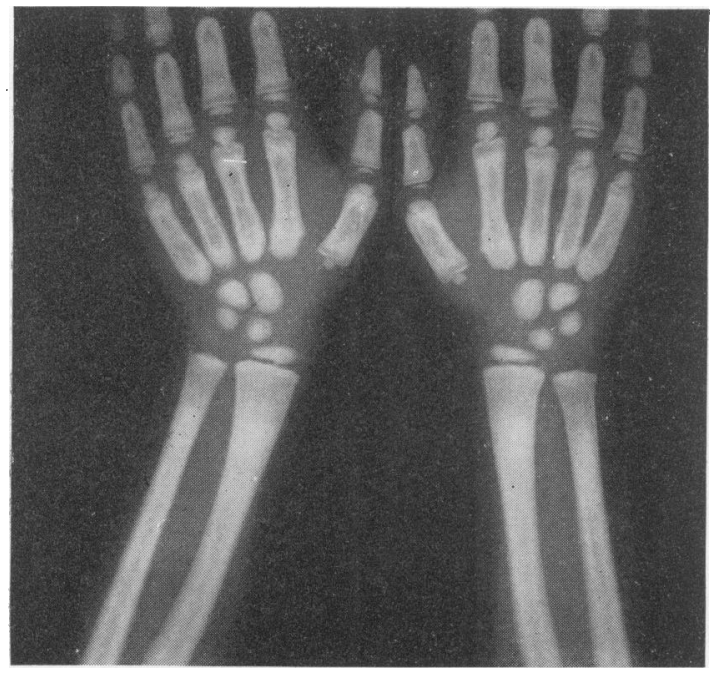

Fig. 8.-Note new bone growth at ends of radius and ulna.

arteries were seen to be delicately outlined by calcium. A month later, films of the wrists showed widened zones of relatively decreased density about the ends of the long bones, presumably representing bone laid down

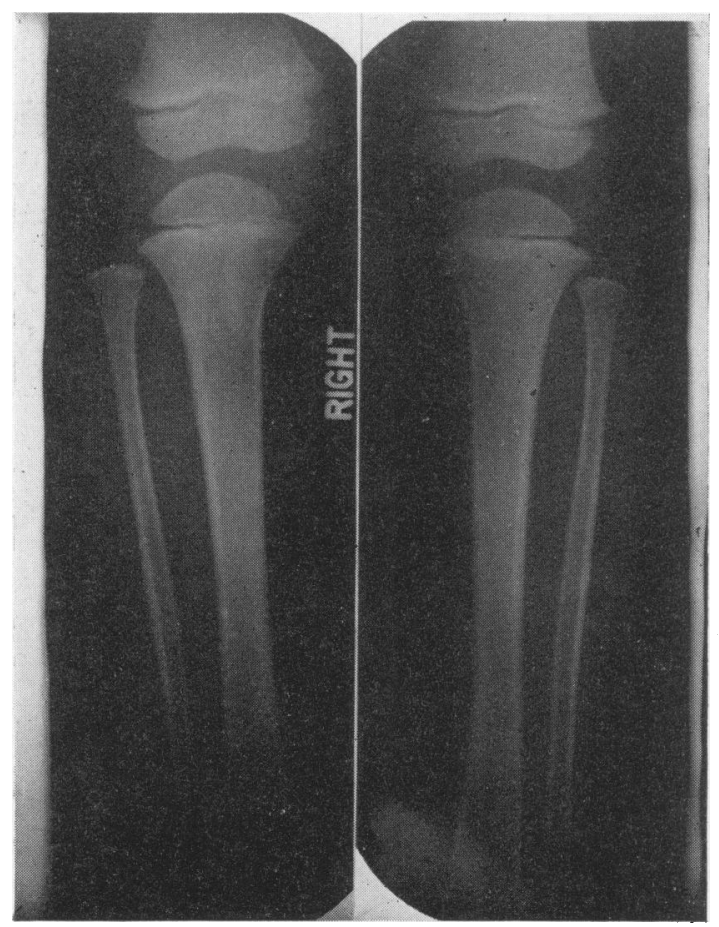

Fig. 9a.-Lower extremities at 5 years. since the patient was taken off massive doses of vitamin (Fig. 8). Periarticular calcification persisted. Bony maturation was about 4 years, definitely retarded for the chronologic age of 6 years and 2 months. Two months later zones of lessened density were seen about the metaphyses adjacent to the knees and ankles (Fig. 9a).

Fifteen months after our first examination, he was taken to his private paediatrician, who kindly provided us with data concerning his course during the next several months. He was kept in hospital at this time because of fever, swelling of face and abdomen, and haematuria, after an upper respiratory infection. He had slight fever, tachycardia, a blood pressure of 180/120 $\mathrm{mm}$. $\mathrm{Hg}$, and moderate oedema of face and abdomen. Treatment was instituted with strict bed rest, penicillin and moderate salt restriction. Parenteral reserpine and 'apresoline' (hydrallazine) were given for one week, with a drop in blood pressure to $130 / 85 \mathrm{~mm}$. $\mathrm{Hg}$. An intercurrent viral gastro-enteritis was followed by loss of facial oedema and ascites. Blood pressure remained between $130 / 90$ and $110 / 80 \mathrm{~mm}$. $\mathrm{Hg}$ without further hypotensive drugs. His weight had dropped to $40 \mathrm{lb}$. from $48.5 \mathrm{lb}$. on admission. His urine which had many red cells on admission, cleared to 20-25 per h.p.f. and he was discharged home.

Radiographs during this period revealed bone density to be less than previously. Calcifications were present in the falx cerebri and tentorium. Periarticular calcifications were still evident about the hips. The transverse diameter of the heart was at the upper limit of normal. Renal shadows were moderately dense. The tip of the 12th rib was apparently fractured. Bony maturation was about 4 years, compared with the chronological age of 6 years and 10 months.

Laboratory studies during this period and for the next several months are tabulated (Table 1). The blood pressure remained near $120 / 90 \mathrm{~mm}$. $\mathrm{Hg}$ on hypotensive therapy. The urine continued to show albumin, red blood cells and casts. The blood sedimentation rate and non-protein nitrogen remained elevated.

The family did not follow the rigid routine of bed rest prescribed, and sent him to school without medical permission.

When he was seen by the author one year after being in hospital under Dr. Woltmann, he was an alert, 7-yearold boy with a uraemic odour and marked pallor. Blood pressure was $190 / 130 \mathrm{~mm}$. Hg. The fundus showed moderate crossing changes but no haemorrhages or papilloedema. Lungs were clear. The heart was enlarged to percussion and had loud tones of poor quality. There was a late diastolic sound suggestive of a presystolic murmur. The abdomen showed no abnormalities. There was no ascites or oedema. Skeletal survey by radiograph at this time showed continued loss of bone density (Fig. 9b). Bone of more normal density had been laid down since vitamin dosage had been discontinued. The overall decrease in density had been spectacular. Soft tissue calcifications were still demonstrated in the tissues about the hips. Chest film showed the heart to be moderately enlarged. The renal shadows had decreased in size and were increased in 
TABLE 1

LABORATORY FINDINGS DURING 1957

\begin{tabular}{|c|c|c|c|c|}
\hline $\begin{array}{c}\text { Date } \\
(1957)\end{array}$ & Urinalysis & $\begin{array}{l}\text { Haemoglobin } \\
\text { (g. } / 100 \mathrm{ml} .)\end{array}$ & $\begin{array}{c}\text { Non-protein } \\
\text { Nitrogen } \\
\text { (mg./100 ml.) }\end{array}$ & $\begin{array}{c}\text { Sedimentation Rate } \\
\text { (mm./hr) } \\
\text { (Wintrobe) }\end{array}$ \\
\hline $\begin{array}{l}\text { February } 28 \\
\text { March } 28 \\
\text { May } 16 \\
\text { September } 12\end{array}$ & $\begin{array}{l}4+\text { albumin; } 10-13 \text { R.B.C.; 3-4 W.B.C.; many casts } \\
4+\text { albumin; } 12-15 \text { R.B.C.; 10-14 W.B.C.; many casts } \\
3+\text { albumin; 8-10 R.B.C.; 10-12 W.B.C.; granular } \\
\text { casts } \\
\begin{array}{l}4 \text { albumin; 6-8 R.B.C.; 10-12 W.B.C.; granular } \\
\text { casts }\end{array}\end{array}$ & $\begin{array}{l}12 \\
13 \cdot 4 \\
13 \cdot 4 \\
10 \cdot 7\end{array}$ & $\begin{array}{r}76 \\
76 \\
72 \\
103\end{array}$ & $\begin{array}{l}40 \\
44 \\
39 \\
92\end{array}$ \\
\hline
\end{tabular}

density, although no definite calcifications were identified.

An electrocardiogram was within normal limits. Blood studies and urine analysis are tabulated (Table 2). A grave prognosis was given and a low protein diet omitting milk was advised. In spite of this, however, the family insisted he attend school if at all possible. The next few weeks saw development of widespread ecchymosis, oozing of blood from the nose, and increased depth of breathing with gallop rhythm. The family called in a physician living near them, who supervised his home care. He died soon after being readmitted to hospital.

Autopsy. Autopsy revealed small amounts of fluid in the peritoneal and pericardial cavities. The heart weighed $268 \mathrm{~g}$. The left ventricle measured $14 \mathrm{~mm}$. in thickness. There were some atherosclerotic changes in the first part of the aorta. The coronary ostia were patent. Both lungs were dark red and firm posteriorly, appearing juicy, bloody, and mucopurulent on cut section. The gastrointestinal tract showed haemorrhagic spots in the stomach and first portion of the duodenum. There was an intestinal intussusception about $6.5 \mathrm{~cm}$. in length, approximately $90 \mathrm{~cm}$. above the ileocaecal valve. The liver was abnormally heavy at $850 \mathrm{~g}$. Cut surface showed fatty change. The spleen, pancreas and adrenals were normal.

Both kidneys were embedded in a small amount of

TABLE 2

TERMINAL LABORATORY STUDIES

\begin{tabular}{|c|c|}
\hline Laboratory Studies & Findings \\
\hline Urinalysis & $\begin{array}{l}\text { Sp. gr. } 1,012, p H \text { He } 6.0 \text { albumin } 4+\text {; } \\
\text { sugar negative, 15-25 W.B.C., } \\
\text { 4-6 R.B.C., occasional epithelial } \\
\text { cell, occasional broad coarse casts, } \\
\text { occasional coarse granular cast, } \\
\text { occasional broad W.B.C. cast }\end{array}$ \\
\hline Complete blood count & $\begin{array}{l}\text { Hb } 5.9 \text { g. } / 100 \mathrm{ml} \text {., W.B.C. } 10,900 \text {; } \\
\text { polymorphs } 65 \text {, lymphocytes } 22 \text {, } \\
\text { basophils } 1 \text {, monocytes } 9 \text {, eosino- } \\
\text { phils } 3 \text {, haematocrit } 18 \%\end{array}$ \\
\hline Serum creatinine & $6.1 \mathrm{mg} . / 100 \mathrm{ml}$ \\
\hline Blood urea nitrogen & $108 \mathrm{mg} . / 100 \mathrm{ml}$. \\
\hline Serum $\mathrm{K}$ & $4.7 \mathrm{mEq} /$ litre \\
\hline Serum alkaline phosphatase & $8 \cdot 0$ Bodansky units \\
\hline Serum inorganic phosphorus & $9.2 \mathrm{mg} . / 100 \mathrm{ml} .(5 \cdot 3 \mathrm{mEq} /$ litre $)$ \\
\hline Serum calcium & $8.4 \mathrm{mg} . / 100 \mathrm{ml} .(4.1 \mathrm{mEq} /$ litre $)$ \\
\hline
\end{tabular}

fat. The right kidney weighed $47 \mathrm{~g}$. (normal $74 \mathrm{~g}$.) and the left kidney weighed $53 \mathrm{~g}$. (normal $75 \mathrm{~g}$.). On cut surface the capsule stripped with difficulty. After removal of the capsule the surface of both kidneys appeared granular. The pelvis appeared normal.

Lymphoid tissue was grossly normal. The thyroid showed cystic change. The parathyroid glands appeared normal. The bone marrow was deep red-brown in

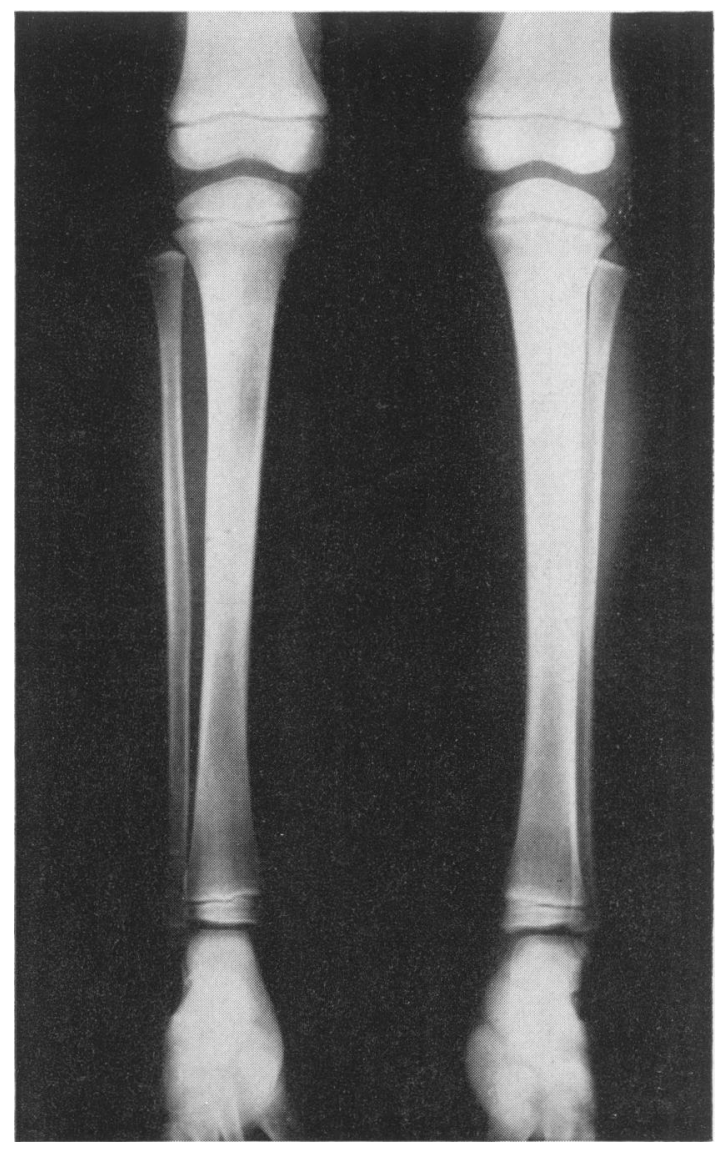

FIG. 9b.-Lower extremities at $7 \frac{1}{2}$ years, showing course of sclerotic bony process. 


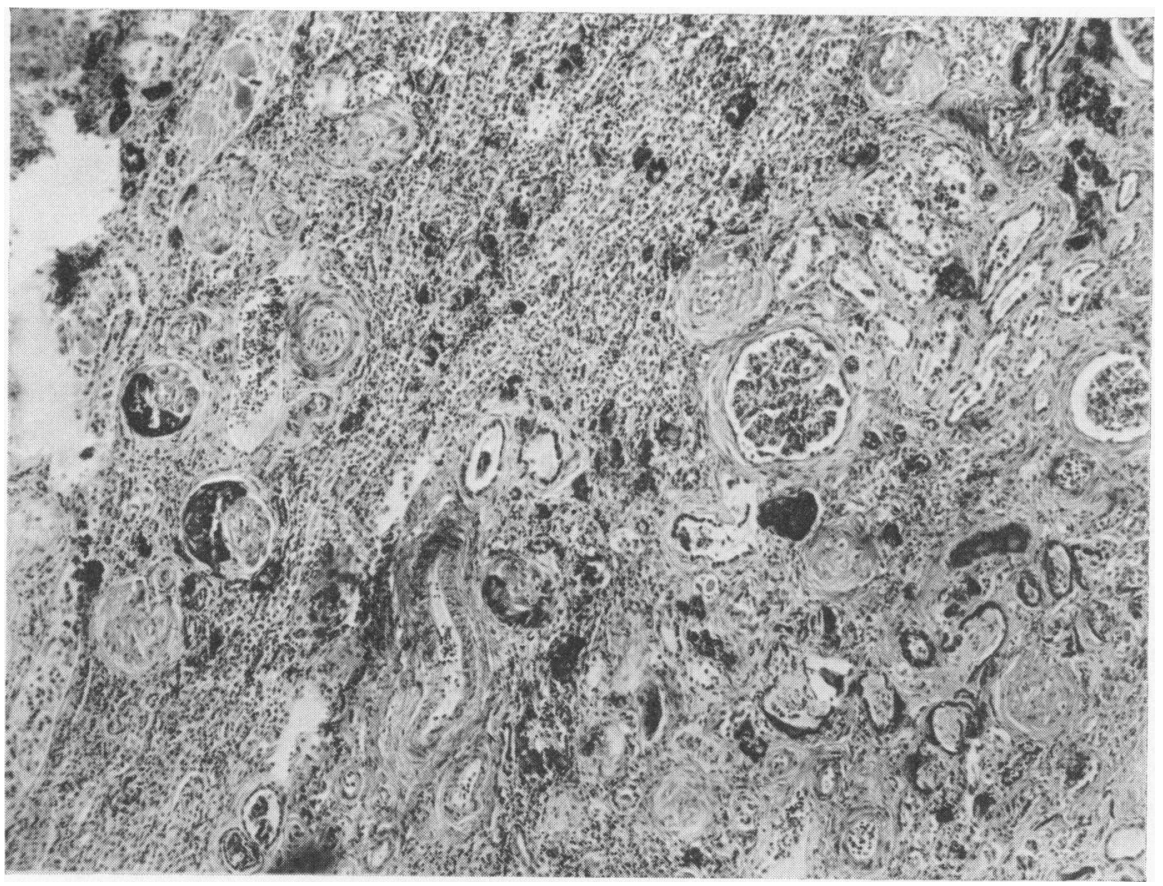

FIG. 10.-Autopsy section of kidney. ( $\quad$ 73.)

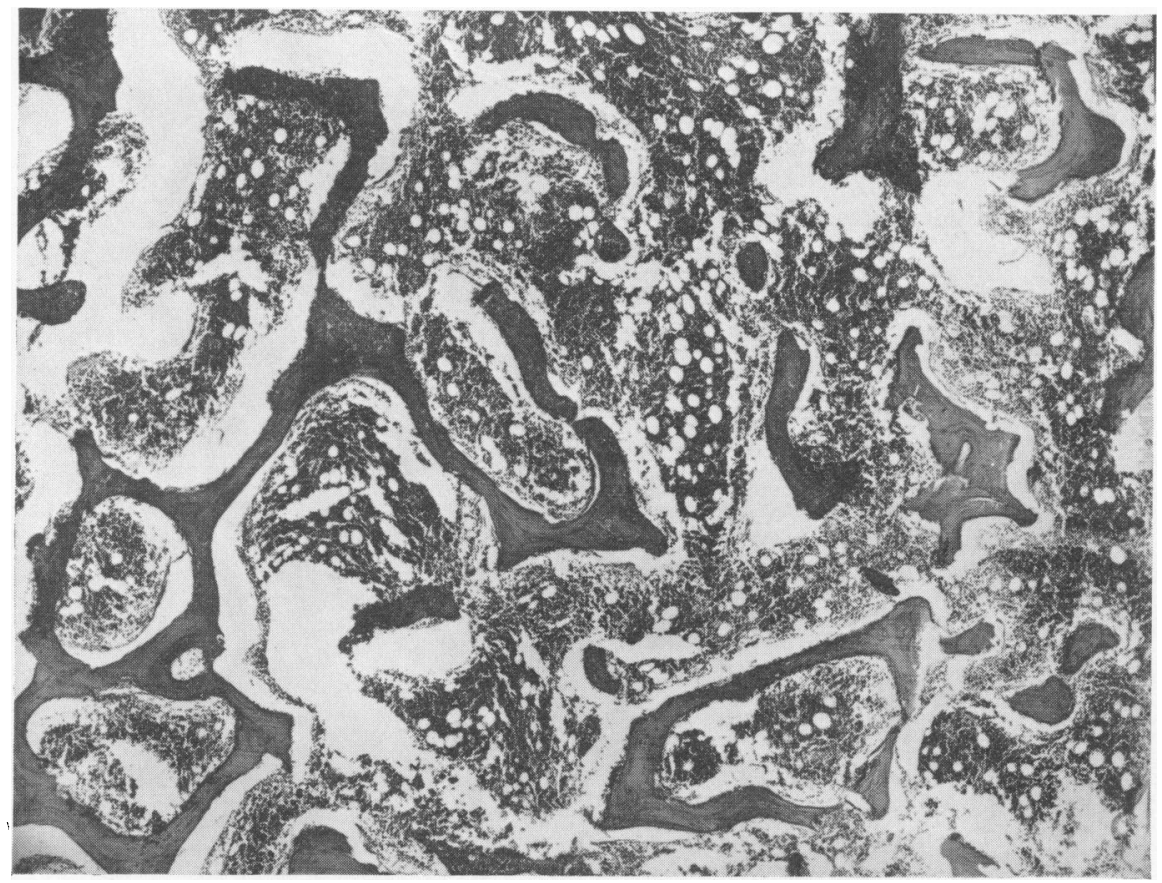

Fig. 11.-Autopsy section of bone marrow. ( $\times 34$.)

음

흥ํㅇ 
colour. The brain was grossly normal, but was increased in weight to $1,365 \mathrm{~g}$. The pituitary gland was normal.

On microscopic section, the heart showed hypertrophy and coronary atherosclerosis. The lungs showed metastatic calcification of the alveolar wall and peribronchial tissue. There was uraemic pneumonitis. The gastrointestinal tract showed haemorrhage in the small intestine and multiple metastatic calcification of gastric glands. There was minimal fatty change in the liver. Metastatic calcification was present in the adrenal glands, but not in the spleen or pancreas. The pathologist's description of the kidney sections follows:

'Practically all glomeruli are fibrotic and there is very extensive atrophy of tubules. What glomeruli remain show at times adhesions and at times crescent formation. There is a marked interstitial fibrosis and inflammatory reaction with striking deposition of calcium throughout the renal parenchyma. Calcium is found in both cortex and medulla. At times it lies within tubular cells, at other times within glomeruli and most frequently appears to lie interstitially. There is extensive intimal proliferation of both small arteries and arterioles.' (See Fig. 10.)

The bone marrow (Fig. 11) showed osteoporosis. Parathyroid tissue was hyperplastic.

\section{Discussion}

Increased density of bone is seldom seen and always presents an interesting problem in diagnosis. The possibility of marble-bone disease was quickly dismissed when the serum calcium level was reported. It appeared highly likely that the excessive ingestion of vitamin D was the cause of his presenting complaints and striking findings. It is not possible to exclude hypervitaminosis $\mathbf{A}$. Vitamins $\mathbf{A}$ and $\mathbf{D}$ are combined in most dose forms, and information regarding exact dose form is not available in the present instance.

That the excess deposit of mineral is actually a result of excessive vitamin ingestion seems likely in view of the following considerations. First, the history and findings apart from the skeleton are consistent with the known syndrome of vitamin D intoxication. Second, the dose and duration of ingestion of vitamin $D$ were greatly excessive. Third, reported cases of vitamin $\mathrm{D}$ intoxication with bone demineralization were mostly older people and patients with rheumatoid arthritis. It is plausible to believe that skeletal maturity does not favour deposition of mineral salts. Furthermore, metabolic forces against skeletal mineralization exist in rheumatoid arthritis, an inflammatory disease with catabolic, or at least anti-anabolic effect on bone and other supporting structures.

It seems reasonable that a child's growing skeleton would react to a high concentration of circulating calcium by incorporating it in the skeleton at areas of epiphyseal and membranous growth. The distribution of excess mineral deposit in long bones is consistent with this type of orderly deposition. Known actions of vitamin $D$ relate to improved absorption of calcium and phosphorus, rather than to specific effects at the level of bone mineralization. Thus it should be possible to correlate skeletal calcification with the level of serum calcium. A study of the ionized calcium level would have been valuable.

A striking parallel to the present case is seen in the cases reported as 'idiopathic hypercalcaemia' (Lowe, Henderson, Park and McGreal, 1954; Creery and Neill, 1954; Creery, 1953; Payne, 1952; Lightwood, 1952; Fellers and Schwartz, 1958; Fanconi, Girardet, Schlesinger, Butler and Black, 1952). The main clinical and laboratory features are similar, except for the onset and duration, and the presence of the 'elfin facies' and associated sequelae.

An interesting feature of the present case is the prompt reversal of bone density on discontinuance of vitamin D therapy. This began before evidence of renal failure appeared. Later progressive bone demineralization should properly be ascribed to renal failure with accompanying acidosis. A finding supporting this view is the presence at autopsy of osteoporosis in the bone sections, representing loss of more than the expected amount of bone substance. Closer observation of calcium metabolism might have changed the outcome. It is known that renal damage secondary to hypervitaminosis $D$ is reversible. The presence of a constant steady stream of calcium from bone to blood stream was undoubtedly responsible for progressive unrelenting renal damage. It was not possible to test the effect of cortisone or other drugs on the serum calcium level.

The chief value of the present case report appears to be the demonstration of a mechanism for quantitative increase in bone mineral in humans. Many interesting studies could be planned on similar cases. It is hoped that the report of this case will stimulate others to make further careful observations in the rarely available similar situation.

\section{Summary}

A case report of a young boy who ingested large quantities of vitamin $D$ over a period of one year demonstrates that reversible increase in bone density may occur, with severe calcinosis and fatal renal failure.

The extent and distribution of the osteosclerosis differs from that reported in vitamin $D$ overdosage in children and resembles somewhat the picture seen in the severe cases of 'idiopathic hypercalcaemia'. 
I am indebted to R. S. Cleland, M.D., of the Children's Hospital of Los Angeles for permission to reproduce microscopic slides and to paraphrase and quote from the autopsy report. Credit is also due to Richard Schreiber, M.D., of the Orthopaedic Hospital, for aid in describing x-ray findings. George R. Woltmann, M.D., of the Children's Hospital staff was kind enough to provide data from his office files.

\section{REFERENCES}

Anning, S. T., Dawson, J., Dolby, D. E. and Ingram, J. T. (1948). The toxic effects of calciferol. Quart. J. Med., 17, 203.

Creery, R. D. G. (1953). Idiopathic hypercalcaemia of infants. Lancet, $2,17$.

- and Neill, D. W. (1954). Idiopathic hypercalcaemia in infants with failure to thrive. Ibid., 2, 110 .

Danowski, T. S., Winkler, A. W. and Peters, J. P. (1945). Tissue calcification and renal failure produced by massive dose vitamin D therapy of arthritis. Ann. int. Med., 23, 22.

Debré, R. (1948). Toxic effects of overdosage of vitamin $D_{2}$ in children. Amer. J. Dis. Child., 75, 787.
Fanconi, G., Girardet, P., Schlesinger, B., Butler, N. and Black, J. (1952). Chronische Hypercalcämie, kombiniert mit Osteosklerose, Hyperazotämie, Minderwuchs und kongenitalen Missbildungen. Helv. paediat. Acta, 7, 314

Fellers, F. X. and Schwartz, R. (1958). Etiology of the severe form of idiopathic hypercalcemia of infancy: a defect in vitamin D metabolism. New Engl. J. Med., 259, 1050

Freeman, S., Rhoads, P. S. and Yeager, L. B. (1946). Toxic manifestations associated with prolonged Ertron ingestion. J. Amer. med. Ass., 130, 197.

Howard, J. E. and Meyer, R. J. (1948). Intoxication with vitamin D. J. clin. Endocr., 8, 895.

Jeans, P. C. (1950). Vitamin D. J. Amer. med. Ass., 143, 177.

Lightwood, R. (1952). Idiopathic hypercalcaemia in infants with failure to thrive. Arch. Dis. Childh. (abstracts), 27, 302.

Lowe, K. G., Henderson, J. L., Park, W. W. and McGreal, D. A. (1954). The idiopathic hypercalcaemic syndromes of infancy. Lancet, 2, 101.

Payne, W. W. (1952). The blood chemistry in idiopathic hypercalcaemia. Arch. Dis. Childh. (abstracts), 27, 302.

Ross, S. G. (1952). Vitamin D intoxication in infancy. Report of 4 cases. J. Pediat., 41, 815 .

- and Williams, W. E. (1939). Vitamin D intoxication in infancy. Amer. J. Dis. Child., 58, 1142.

Thatcher, L. (1931). Hypervitaminosis-D, with report of a fatal case in a child. Edinb. med. J., 38, 457.

Tumulty, P. A. and Howard, J. E. (1942). Irradiated ergosterol poisoning: report of two cases. J. Amer. med. Ass. 119, 233. 